\title{
Covid-19 pandemic and global tourism
}

\author{
Stevan Luković ${ }^{1}$, Dragan Stojković ${ }^{*}$ \\ ${ }^{1}$ University of Kragujevac, Faculty of Economics, Kragujevac, Serbia
}

\begin{abstract}
The tourism industry represents a significant part of the global economy. However, tourism demand is very sensitive to crisis events, such as economic crises, epidemics, pandemics, natural disasters and terrorist attacks. Regarding this, the primary research goal of the paper is to analyze the impact of the Covid-19 disease on global tourism. During 2020, in order to prevent further spread of this contagious disease, almost all countries in the world have introduced a ban on movement, closing of borders and other important health measures. The review of the relevant literature provided in the paper shows that the introduced measures have a negative impact on the global hospitality, travelling and tourism industry.
\end{abstract}

Keywords: SARS, Covid-19, tourism, epidemic, pandemic

JEL classification: I15, Z32

\section{Pandemija Covid-19 i globalni turizam}

Sažetak: Turistička delatnost predstavlja značajan segment svetske privrede. Međutim, turistička potražnja je veoma osetljiva na krizna dešavanja, kao što su ekonomske krize, epidemije, pandemije, prirodne nepogode i teroristički napadi. S tim u vezi, osnovni cilj rada jeste analiziranje uticaja bolesti Covid-19 na globalni turizam. Tokom 2020. godine gotovo sve zemlje sveta su, u cilju sprečavanja daljeg širenja ove zarazne bolesti, uvele zabranu kretanja, zatvaranje granica i ostale važne zdravstvene mere. Pregledom relevantne literature je utvrđeno da su preduzete mere ostvarile veoma negativan uticaj na sektore globalne ugostiteljske, putničke i turističke industrije.

Ključne reči: SARS, Covid-19, turizam, epidemija, pandemija JEL klasifikacija: I15, Z32

\section{Introduction}

Tourism is considered an important industry that accounts for $10 \%$ of the global GDP, $7 \%$ of international trade and $30 \%$ of services. In this regard, 1 out of 10 jobs globally could be attributed to tourism (Chebly \& Said, 2020). Until the outbreak of the Covid-19 pandemic, the tourism industry was one of the world's largest consumer markets. Significant growth of international tourism in the past decades has been the result of the influence of various factors, especially the development of new technologies, new life styles related to global prosperity, as well as the growth of low-cost airlines that made international travel available to wider audience. The enormous tourism development in past decades "can also be attributed to the emergence of the middle class in large and developing economies, such as China, Brazil and India” (RTE, 2020 as cited in Folinas \& Metaxas, 2020, p. 2). The

*dstojkovic@kg.ac.rs 
movement of people and tourism revenue has had a significant impact on the development of economies around the world (Grubor et al., 2019; Maksimović et al., 2019). Moreover, tourism is often the most important industry in regions that manufacture considers unattractive for investments (Počuča \& Matijašević-Obradović, 2020). Tourists spend on sporting events and festivals, shopping, accommodation, restaurants, tourist attractions, while business passengers spend on conferences and other events, which stimulates the local economy and employment (Folinas \& Metaxas, 2020). However, the tourism sector is very sensitive to crisis events, because when discouraging news is heard, passengers immediately decide to cancel or postpone their travels. In this regard, pandemic outbreaks are extremely pessimistic news for travelers, because in case of travel to distant destinations it can be difficult not to contract the disease. In addition, not only are passengers in danger, but also people who come in contact with them (Uğur \& Akbıyık, 2020). The novel coronavirus represents just that, both an epidemic and a pandemic.

“Coronavirus is a virus of severe acute respiratory syndrome (SARS) mainly transmitted from animals to humans. The virus was most likely transmitted from birds to humans in 2002" (Uğur \& Akbıyık, 2020, p. 1), when more than 8,000 people became ill between November 2002 and June 2003. The largest number of infected people was in China (almost two thirds) and Hong Kong (one fifth) (Mackyi \& Liang, 2012). Also, a large number of infected and deadly cases were in Taiwan, Singapore and Canada. In late 2019, the coronavirus caused the emergence of another major virus, SARS-CoV-2. After 9,800 cases of infection and 213 deaths were recorded, the World Health Organization (WHO) classified Covid-19 as a public health threat of international importance at the end of January 2020. Five weeks later, when 118,000 cases of infection and 4,291 deaths were recorded in 114 countries, the WHO declared a pandemic on March 11 (Ghebreyesus, 2020). Thus, this severe acute respiratory syndrome spread rapidly around the world, leading to a global pandemic of the disease. Given that even ten months after the outbreak there is still no effective and proven vaccine for Covid-19, almost all countries have been forced to introduce travel bans. By July 1, 2020, the disease had caused over 500,000 reported deaths worldwide (Weed, 2020), while in early November 2020 the number was more than 1.2 million (Worldometer, 2020).

"The negative impact of Covid-19 is not limited to the loss of human lives, but also has short-term and long-term social, economic and political effects” (Farzanegan et al., 2020, p. 1). Organization for Economic Cooperation and Development (OECD) projections show that the intensive spread of Covid-19 is likely to cause a 1.5\% drop in global economic growth in 2020, which is half of the projected growth rate before the outbreak (OECD, 2020). Also, "International Monetary Fund (IMF) predicts that Covid-19 will cause a global recession in 2020 that could be even worse than Global financial crisis in 2008” (Farzanegan et al., 2020, p. 1). Great restrictions on global travel and warnings to stay at home have led to the most serious collapse of the global economy since World War II. Since the ban on international travel has affected over $90 \%$ of the world's population, and intra-community movement bans were imposed, tourism industry was effectively paralyzed in March 2020 (Gössling et al., 2020). Thus, the travel and tourism sectors have shown a high vulnerability to the crisis caused by Covid-19, because this crisis has particularly affected passengers' demand. Travelling between different territories and the overall movement of people has become strictly controlled. Regarding this, hospitality industry, air transport, cruising and car rental are four industries that have experienced a large decline due to the pandemic (Sharma \& Nicolau, 2020). As a result, most of the resorts and hotels remained completely empty for most of 2020 .

Having in mind the above, the paper aims to clarify the impact of Covid-19 pandemic on global tourism by reviewing the relevant literature that deals with this matter. The qualitative 
analysis conducted in the paper should contribute to a better understanding of negative effects of this pandemic on the global tourism industry.

\section{The outbreak and spreading of Covid-19}

SARS is a respiratory disease that first appeared in 2003 in southern China (Guangdong province), after which it spread to North America and Europe. The official number of SARS infections worldwide was 8,096, while 774 deaths were recorded (Smith, 2006; WHO, 2004). The emergence of SARS in 2003 caused great concern at the international level due to its transmission dynamics, and simultaneously led to large economic losses in global tourism. The impact of the spread of SARS was reflected in the decrease of the number of international tourists, which fell by 42.83\% during the second quarter of 2003 and $7.24 \%$ during the third quarter of the same year (Feng-Juan \& Feng-Jie, 2013). Even then, it was obvious that such and similar events have a great negative impact on the tourism industry, because of its sensitivity to external shocks (Polyzos et al., 2020).

Seventeen years later, a new virus with similar characteristics appeared in China. The first cases of infection were reported in the live-animal markets in Wuhan. Further analysis determined that the pathogen that caused viral pneumonia in infected people is coronavirus. The new coronavirus has been officially named SARS-CoV-2, while the disease has been named Covid-19. Covid acronym stands for Corona Virus Disease, while the number denotes the year when the disease started to spread (Uğur \& Akbiyık, 2020). Wuhan (Hubei Province) experienced an epidemic of SARS-CoV-2 virus in mid-December 2019 (Farzanegan et al., 2020; Yang et al., 2020). Regarding this development, on December 31, 2019, China sent a warning to the WHO that several cases of unusual pneumonia had occurred in Wuhan and that some of the infected people visited city markets. At the beginning of 2020, the disease spread quickly in China and later to most of the other countries. On January 31, 2020, WHO declared the outbreak of the disease Covid-19 a public health threat of international importance. At the beginning of March 2020, Covid-19 was reported for more than 1.4 million people (Folinas \& Metaxas, 2020). So, in just a few weeks, the disease has spread all over the world and seriously endangered the lives of a large number of people, especially in East Asia, Europe and North America (Baum \& Hai, 2020). The rapid spread of the virus forced the WHO to declare a global pandemic of Covid-19 on March 11, 2020. Also, after the spread of the disease in Italy, Spain, France, Germany and the United Kingdom, on March 13, 2020, the WHO announced that Europe had become the new pandemic epicenter. By the beginning of November 2020, over 50 million cases of Covid-19 and over 1.2 million deaths were recorded worldwide (Worldometer, 2020).

Covid-19 primarily affects lungs and respiratory tract and causes mostly respiratory symptoms. Most people who become infected with Covid-19 have mild symptoms and recover without the need for specialist treatment. However, the elderly and people with weakened immunity have an increased probability of becoming seriously ill. "This disease is transmitted from person to person through droplets from the nose or mouth that spread when the infected person coughs, sneezes or exhales" (Jones \& Comfort, 2020, p. 77). Since testing is limited in many countries, due to the shortage of tests and adequate medical equipment, asymptomatic people are thought to be unconsciously transmitting the virus in large numbers (Gössling et al., 2020; Li et al., 2020). Regarding this, people without obvious symptoms spread virus even before they become aware, they need to go into self-isolation or take other actions, such as physically distancing themselves in public or covering noses and mouths to prevent the virus from spreading while talking, coughing or sneezing.

The rapid spread of Covid-19 has created significant pressures in health systems of many countries. These pressures are especially evident in the provision of a sufficient number of 
adequately equipped rooms in hospitals, medical equipment and devices for the treatment of gravely ill patients, sufficient number of medical staff employees and adequate facilities and testing instruments (Jones \& Comfort, 2020). In order to prevent further spread of SARS$\mathrm{CoV}-2$, almost all countries in the world have defined a number of restrictions related to the movement of people and travel. However, these travel ban measures have had a major negative impact on the tourism industry and the global economy (Hoque et al., 2020). Tourism requires travelling, so any factor that is an obstacle to travel can significantly affect the tourism industry.

\section{The impact of Covid-19 on tourism}

The emergence of epidemics and pandemics negatively affects the development of the tourism industry. Regarding this, the fact that they occur more and more often in modern conditions is particularly troublesome. During the 20th century, only three pandemics were recorded (Gössling et al., 2020): "the so-called 'Spanish' flu or influenza of 1918-1919, 'Asian' flu $\left(\mathrm{H}_{2} \mathrm{~N}_{2}\right)$ of 1957 and 'Hong Kong' flu of 1968” (p. 4). However, there have been five pandemics recorded in the 21st century: SARS in 2002, bird flu in 2009, MERS in 2012, Ebola in 2013-2014 and SARS-CoV-2 in 2019. The frequent outbreak of pandemics in the 21st century can be attributed to factors of global changes. Some of these factors are: "rapid growth of the global population and its mobility, urbanization, industrialized food production in global value chains, increased food consumption (especially meat), and the development of global traffic networks" (Gössling et al., 2020, p. 3). However, in recent decades, the global tourism industry has suffered significant losses that are not related to epidemics, but are the result of a series of unfortunate climatic and geopolitical events (tsunamis, hurricanes, earthquakes, terrorism and such) (Polyzos et al., 2020). In this regard, the major events that caused the collapse of the tourism industry in the 21st century include the terrorist attack of September 11 (2001), the outbreak of the virus causing severe acute respiratory syndrome (SARS) (2003), the Global economic crisis in 2008/2009, the outbreak of the virus that causes Middle Eastern acute respiratory syndrome (MERS) (2015) and SARS-CoV-2 (2019). Until the spreading of Covid-19, it was assumed that tourism as a system was largely resistant to external shocks. However, the impact of this virus on the tourism industry is unprecedented, as the consequences of Covid-19 are far more pronounced than in the previous crises (Gössling et al., 2020).

The rapid spread of Covid-19 has significantly affected global tourism, which has suffered serious consequences (Estrada et al., 2020), especially attractive tourist destinations, such as France, Italy and Spain, but also countries where outbound tourism is extremely widespread, such as China and the United States (Farzanegan et al., 2020). The news that the virus has spread has caused great concern among tourists, potential tourists and the wider tourism industry. A global wave of cancellations and postponements of tourist and business arrangements followed. The International Air Transport Association (IATA, 2020) reported that the coronavirus would reduce global air traffic revenues by $\$ 29.3$ billion in 2020 . This is the first decline of its kind since the Global financial crisis of 2008, and almost $95 \%$ of the projected loss relates to carriers from the Asia-Pacific region (Folinas \& Metaxas, 2020). According to a CNBC report, almost 200,000 flights from and to China were canceled in 2020. Also, "many cruise lines, such as the Norwegian Cruise Line and Royal Caribbean, have suspended sailing from and to China” (Hoque et al., 2020, p. 1).

Chinese tourism is considered one of the world's largest tourism markets when it comes to both inbound and outbound tourism. Chinese tourists make up more than $10 \%$ of the world's tourists. "China's annual revenue from the tourism industry is about CNY5.128 billion" (Hoque et al., 2020, p. 1). However, when the coronavirus spread, the Chinese tourism 
industry suffered a significant drop. World tourists who have booked holidays to many destinations in China, such as Beijing, Shanghai, Xi'an and Chengdu, have canceled or rerouted these reservations to other destinations, such as South Africa, the Maldives and Australia (Dezan Shira \& Associates, 2020). Singapore, the United States and Australia immediately banned the entry of foreign nationals who visited China. However, the pandemic spread quickly in the United States, where, as in other countries, it caused an economic crisis. In this regard, the U.S. policy makers were forced to adopt draft plans for economic recovery. Citizens were invited to stay in their homes and received support in the form of financial assistance. Small businesses also received financial and tax incentives, while large corporations delivered requests for more financial assistance (roughly the amounts they received at the beginning of the economic crisis in 2008) (Sharma \& Nicolau, 2020).

World Travel and Tourism Council (WTTC) argue that Covid-19 would have severe consequences on the global tourism industry by reducing travel by $25 \%$ in 2020 and generating a loss of 50 million jobs that would require at least ten months for this industry to recover. The effects of the pandemic are closely correlated with the degree of the implemented restrictive measures, using a U.S. administration ban on travels to Europe as an example (Folinas \& Metaxas, 2020).

The first projections of the United Nations World Tourism Organization (UNWTO) for 2020 are that international travels will fall by 20-30\% compared to 2019 (Chebly \& Said, 2020). A 20-30\% drop in tourism activities will bring down international tourism revenue by about $\$ 300-450$ billion. That is “almost a third of the $\$ 1.5$ trillion market" (Polyzos et al., 2020, p. 2). However, in the first half of 2020 , there were as many as $65 \%$ fewer international tourist arrivals compared to the same period in 2019. It is estimated that international tourist arrivals fell by $78 \%$ and led to a loss of $\$ 1.2$ billion in revenues from tourism, as well as a direct loss of 120 million jobs in tourism industry, which is seven times larger than the impact of September 11 and the biggest drop in history (UNWTO, 2020). Hence, decisive measures must be introduced to support tourism in order to save it from rapid declining. Employees in the tourism industry are not the only economic agents that are facing the negative impact on revenues, but also many related industries, so many economic sectors may suffer damage. It should also be noted that "the tourism industry is often a source of seasonal income for unskilled workers, usually originating from lower-income groups. In this sense, the adverse impact on tourism can also increase income imbalances and harm social justice” (Polyzos et al., 2020, p. 11).

Covid-19 pandemic has caused economic and social consequences for the sustainable development of countries whose GDP is substantially contributed by tourism. In most of the countries, governments have introduced measures to prevent job losses, but many travel companies are managed by self-employed persons and families who often do not qualify for state aid packages. This has happened especially in "small and less developed countries (e.g. Maldives and Seychelles) where tourism accounts for over 50\% of gross domestic product" (Jones \& Comfort, 2020, p. 79).

Measures taken to prevent the spread of Covid-19 (e.g., social distancing, travel and movement bans, community movement bans, self-isolation, gathering restrictions) have stopped global travel, tourism and leisure activities. As tourism is one of the most important parts of global employment and important factor contributing to GDP in several countries, the impact of Covid-19 on tourism is a topic of many international debates (Sigala, 2020). 


\section{Post-Covid global tourism}

It can be assumed that after the Covid-19 pandemic tourism will go through certain transformations, whereby tourist strategies and tourists' behavior will most likely change. Regarding this, it will be necessary to conduct adequate analyses that will be helpful in defining future strategies on the basis of accurate data on the pandemic, mortality and its ultimate economic effects.

The most important changes that can be expected in the tourism industry after the Covid-19 pandemic can be summarized as follows:

- People will most likely avoid distant tourist destinations and, vice versa, they will prefer closer ones. The reason for choosing less distant tourist destinations is reflected in reducing the risk of infection, but also the possibility of some of the borders being closed (crossing many borders increases the risk of some of them being closed). The decisions that tourists make in favor of shorter routes can significantly contribute to the more intensive development of domestic tourism;

- The price of international flights will increase as a consequence of reduced tourism demand due to the reduced number of passengers. Also, the increase in flight prices will be additionally influenced by social distancing procedure which airlines must enforce;

- Changes in the cruise industry are expected. In accordance with the redefined tourists' requirements, the average length of cruise is most likely to decrease in the future along with the number of passengers;

- Hotels will also undergo transformations as a result of investing large sums in noncontact technologies and raising hygiene standards. In the future, crowds at receptions will be most likely avoided, reservations will be placed through applications, the use of gyms will be limited to some extent, more frequent surface disinfection will be imposed and other health and hygiene measures will be implemented more intensively. Hygiene and health conditions of tourist destinations will become important factors affecting tourists' decision making;

- The future of large gatherings (e.g. Olympics and Oktoberfest) is uncertain. Due to numerous restrictions imposed on cross-border movements, social distance, temperature control and the reduced number of international airlines, it will be difficult to organize large events that gather millions of people in the same manner as before Covid-19.

In line with the aforementioned potential changes, the tourism industry will have to regain the confidence of travelers in the future, at least when it comes to the risks to which they are exposed. Regarding this, it will be necessary to introduce updated travel insurance, refunds in case of travel cancellation and define adequate policies in case of change of travel plans. Given that travel insurance has become particularly important topic with the Covid-19 outbreak, future tourism industry recovery strategies should include offer of travel arrangements that include travel insurance packages shaped in line with the Covid-19 background.

Also, in the future, the transformation of the global tourism system oriented toward more sustainable economic development should be reconsidered. Covid-19 crisis has pointed out the importance of balance between tourism and sustainable development, reflected in the ecological changes that could be of key importance for the transition to a more sustainable future. 


\section{Conclusion}

The world has experienced many epidemics and pandemics throughout history, but none has had as pronounced consequences for the global economy as the Covid-19 pandemic. In a short time, Covid-19 has caused great panic among people all over the planet. To prevent the further spread of Covid-19, most countries in the world immediately took important health measures, such as movement ban and closing of borders. However, the imposed restrictive measures have had a negative impact on the global economy, especially on the tourism industry. It is estimated that by the end of 2020 a large drop in international tourist arrivals will reduce global tourism industry revenue by about $70 \%$. Thus, Covid- 19 is not only a danger to human life, but also has numerous short-term and long-term negative economic, social and environmental consequences. The impact of Covid-19 on tourism in developing countries is projected to be significantly greater than in developed countries. In some smaller countries where tourism accounts for more than 50\% of GDP (e.g., Maldives and Seychelles) the pandemic has pushed a large part of population to poverty since the tourism is a primary source of income in these countries.

After the end of the Covid-19 pandemic, the tourism industry will most likely experience changes as a consequence of modified attitudes and behavior of tourists and numerous proposals for its future development. Most of the proposals are aimed at providing long-term social distance during air and cruise travels and staying in hotels and restaurants.

The qualitative analysis carried out in the paper has a significant scientific contribution. The theoretical and practical contribution of the paper is reflected in a better understanding of the research subject, which is an important precondition for undertaking adequate economic measures. Although the impact of Covid-19 pandemic on the global economy and tourism is attracting the attention of many researchers, this research topic is still inadequately explored in the relevant literature. In this regard, this paper can be the basis and guideline for some future research. For example, it would be important to conduct a comparative analysis of the economic consequences of the Covid-19 pandemic and the Global financial crisis of 2008, with a special emphasis on their impact on tourism. However, certain limitations are noticed in the conducted research. The main limitations are related to the lack of officially published data regarding Covid-19 economic impact, at least when it comes to economic indicators that measure the impact of the disease on tourism industry.

\section{References}

1. Baum, T., \& Hai, N. T. T. (2020). Hospitality, tourism, human rights and the impact of COVID-19. International Journal of Contemporary Hospitality Management, 32(7), 2397-2407. https://doi.org/10.1108/IJCHM-03-2020-0242

2. Chebly, A., \& Said, F. B. (2020). The impact of Covid-19 on tourist consumption behaviour: A perspective article. Journal of Tourism Management Research, 7(2), 196207. https://doi.org/10.18488/journal.31.2020.72.196.207

3. Dezan Shira \& Associates (2020). The coronavirus in Asia and ASEAN - Live updates by country. ASEAN Business News. Retrieved February 3, 2020 from https://www.aseanbriefing.com/news/coronavirus-asia-asean-live-updates-by-country/

4. Estrada, M., Park, D., \& Lee, M. (2020). How a massive contagious infectious diseases can affect tourism, international trade, air transportation, and electricity consumption? The case of 2019 novel coronavirus (2019-nCoV) in China (February 19, 2020). $\begin{array}{llll}\text { Retrieved November } & 11, & \text { from }\end{array}$ https://papers.ssrn.com/sol3/papers.cfm?abstract_id=3540667 
5. Farzanegan, M. R., Gholipour, H. F. Feizi, M., Nunkoo, R., \& Eslami Andargoli, A. (2020). International tourism and outbreak of coronavirus (COVID-19): A cross-country analysis. Journal of Travel Research. https://doi.org/10.1177/0047287520931593

6. Feng-Yuan, X., \& Feng-Jie, X. (2013). Research note: A study of outliers of international tourism statistics. Tourism Economics, 19(5), 1215-1227. https://doi.org/10.5367/te.2013.0233

7. Folinas, S., \& Metaxas, T. (2020). Tourism: The great patient of coronavirus COVID2019. Munich Personal RePEc Archive (MPRA), Paper No. 99666. Retrieved November 11, 2020 from https://mpra.ub.uni-muenchen.de/99666/1/MPRA_paper_99666.pdf

8. Ghebreyesus, T. A. (2020). WHO Director-General's opening remarks at the media briefing on COVID-19 - 11 March 2020. Retrieved June 29, 2020, from https://www.who.int/director-general/speeches/detail/who-director-general-s-openingremarks-at-the-media-briefing-on-covid-19---11-march-2020

9. Gössling, S., Scott, C. D., \& Hall, M. (2020). Pandemics, tourism and global change: A rapid assessment of COVID-19. Journal of Sustainable Tourism, 29(1), 1-20. https://doi.org/10.1080/09669582.2020.1758708

10. Grubor, A., Leković, K., \& Tomić, S. (2019). Rural tourism marketing of the Danube region. Ekonomika, 65(4), 1-9. https://doi.org/10.5937/ekonomika1904001g

11. Hoque, A., Shikha, F. A., Hasanat, M. W., Arif, I., \& Abu Bakar A. H. (2020). The effect of coronavirus (COVID-19) in the tourism industry in China. Asian Journal of Multidisciplinary Studies, 3(1), 52-58.

12. International Air Transport Association (IATA) (2020). Airlines financial monitor, January - February 2020. Retrieved November 11, 2020, from https://www.iata.org/en/iata-repository/publications/economic-reports/airlines-financialmonitor---feb-2020/

13. Jones, P., \& Comfort, D. (2020). The COVID-19 crisis, tourism and sustainable development. Athens Journal of Tourism, 7(2), 75-86. https://doi.org/10.30958/ajt/v7i2

14. Li, R., Pei, S., Chen, B., Song, Y., Zhang, T., Yang, W., \& Shaman, J. (2020). Substantial undocumented infection facilitates the rapid dissemination of novel coronavirus (SARS-CoV2). Science, 368(6490), 489-493. https://doi.org/10.1126/science.abb3221

15. Mackey, T. K., \& Liang, B. A. (2012). Lessons from SARS and H1N1/A: Employing a WHO-WTO forum to promote optimal economic-public health pandemic response. Journal of Public Health Policy, 33(1), 119-130. https://doi.org/10.1057/jphp.2011.51

16. Maksimović, G., Ivanović, T., Milošević, B., \& Sekulić, D. (2019). Factors of the rural tourism development of Sirinicka Zupa in Kosovo and Metohija. Economics of Agriculture, 66(4), 1187-1199. https://doi.org/10.5937/ekopolj1904187m

17. Organization for Economic Cooperation and Development (OECD) (2020). OECD Economic Outlook, Interim Report. https://doi.org/10.1787/7969896b-en

18. Počuča, M., \& Matijašević-Obradović, J. (2020). Mutual conditionality of the environment and tourism: The importance of monitoring the air quality of the City of Novi Sad in the development and improvement of tourism. LAW - theory and practice, 37(2), 17-34. https://doi.org/10.5937/ptp2002017p

19. Polyzos, S., Samitas, A., \& Spyridou, A. (2020). Tourism demand and the COVID-19 pandemic: An LSTM approach. Tourism Recreation Research. https://doi.org/10.1080/02508281.2020.1777053

20. Sharma, A., \& Nicolau, J. L. (2020). An open market valuation of the effects of COVID19 on the travel and tourism industry. Annals of Tourism Research, 83, 102990. https://doi.org/10.1016/j.annals.2020.102990

21. Sigala, M. (2020). Tourism and COVID-19: Impacts and implications for advancing and resetting industry and research. Journal of Business Research, 117, 312-321. https://doi.org/10.1016/j.jbusres.2020.06.015 
22. Smith, R. D. (2006). Responding to global infectious disease outbreaks: Lessons from SARS on the role of risk perception, communication and management. Social Science \& Medicine, 63(12), 3113-3123. https://doi.org/10.1016/j.socscimed.2006.08.004

23. Uğur, N. G., \& Akbiyık, A. (2020). Impacts of COVID-19 on global tourism industry: A cross-regional comparison. Tourism Management Perspectives, 36, 100744. https://doi.org/10.1016/j.tmp.2020.100744

24. United Nations World Tourism Organization (UNWTO) (2020). Impact assessment of COVID-19 outbreak on international tourism. Retrieved May 18, 2020 from https://www.unwto.org/impact-assessment-of-the-covid-19-outbreak-on-internationaltourism

25. Weed, M. (2020). The role of the interface of sport and tourism in the response to the COVID-19 pandemic. Journal of Sport \& Tourism, 24(2), 79-92. https://doi.org/10.1080/14775085.2020.1794351

26. World Health Organization (WHO) (2004). Summary of probable SARS cases with onset of illness from 1 November 2002 to 31 July 2003. Retrieved November 9, 2020 from https://www.who.int/csr/sars/country/table2004_04_21/en/

27. Worldometer (2020). Retrieved November 9, 2020 from https://www.worldometers.info/coronavirus/

28. Yang, Y., Zhang, H., \& Chen, X. (2020). Coronavirus pandemic and tourism: Dynamic stochastic general equilibrium modeling of infectious disease outbreak. Annals of Tourism Research, 83, 102913. https://doi.org/10.1016/j.annals.2020.102913 